\title{
In Celebration of Prof. Jan Vřešt'ál's 80th Birthday
}

Published online: 2 January 2019

(C) ASM International 2019

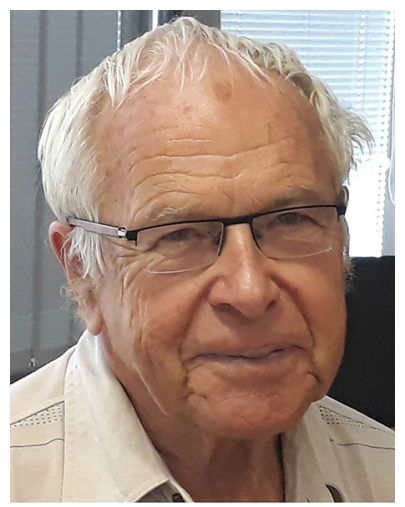

Professor Jan Vřešt'ál

It is hard to believe, but Professor Jan Vřešt'ál, our esteemed colleague and friend, is 80 years old this year. He was born on February 16, 1939, in Brno, Czechoslovakia (as it was known at that time) and managed to become a distinguished scientist and colorful personality despite the difficult times he has lived through.

He began his studies in analytical chemistry in Brno at the Masaryk University in 1956, completing them at the J.E. Purkyně University in 1961. Actually, he did not change locations, rather the university changed its name, as many did in socialist Czechoslovakia in those difficult times. The university was originally named the Masaryk University (after the first president and one of the "founding fathers" of the Czechoslovak Republic) in 1919, but it was renamed in 1960 in honor of the renowned Czech scientist J.E. Purkyně for political reasons; the name of the first Czechoslovak president was not acceptable to the communist government at that time, but the name of the famous nineteenth century scientist was "safe enough" to be approved. The university regained its original name in 1990.

Jan worked as a research fellow at the Institute of Physics of Materials from 1963 to 1991. He supported the reformist movement in the political struggles known as "The Prague Spring" that took place in the late sixties, as many people did at that time. As a consequence, for political reasons, he was not allowed to defend his $\mathrm{PhD}$ thesis until 1984.

After the political changes in 1989 , new possibilities opened for most Czech scientists and students, and Jan became the head of the Thermodynamics and Diffusion Group at IPM ASCR Brno until 1991. Subsequently, he was offered a position in the Department of Physical Chemistry at the Masaryk University in 1992 . He became associate professor there in 1993 and full professor in 1996. He also earned the title DrSc in 1994 (the highest academic research degree awarded in the Czech Republic at that time). Jan was the head of the Department of Physical Chemistry from 1993 to 2004, and a leading personality behind regaining the high scientific standards and excellence that this department enjoyed in earlier more liberal times. He has been a part-time senior researcher and professor emeritus since 2004, and is still very active in research and teaching today.

His research interests cover the thermodynamics of metals and alloys, the modeling of thermodynamic functions and phase diagrams using the CALPHAD method and $a b$ initio approaches, mass spectrometry, and calorimetry. A more detailed overview of his contributions to the field of thermodynamics and CALPHAD modeling is given elsewhere in this special issue.

He has published more than 100 papers in internationally recognized journals and has presented more than 150 
contributions at international conferences. He was the Czech representative and the vice-chair of the Associated Phase Diagram and Thermodynamic Committee, which is an affiliate of the Alloy Phase Diagram International Commission (APDIC). He is a member of the editorial board of Journal of Mining and Metallurgy and has made important contributions to many national and international research teams.

Jan is a great personality. He remains a very active, hardworking scientist of the utmost integrity, an outstanding teacher and organizer, and a congenial colleague and friend. He was the driving force behind the "Brno thermodynamics group," persuading the CALPHAD advisory board to entrust him with the organization of the CALPHAD XXXVIII (2009) meeting, even though he and his coworkers were complete newcomers to the community, having joined in the mid-1990s. Later, he was a member of the organizing committee for the 2014 TOFA conference in Brno, and naturally played a key role.

He has devoted his life not only to science; he has been a keen sportsman and coach, spending much of his rare spare time participating in orienteering and cross-country skiing competitions and successfully introducing new generations of sportsmen to these activities. It did not matter to him whether they were talented or participated just for fun, he instilled in them not only a passion for the sport but also a sense of honesty and fair play.
Despite enthusiastically accepting the role of "the best grandfather in the world" from all of his grandchildren, Jan remains a valuable source of ideas, enviable activity, and indefatigable energy for all of his colleagues and friends. Notwithstanding his "young age," he pushes his colleagues and friends (all of them significantly younger) into many new activities, making it very difficult for them to accept the embarrassing fact that he is usually more active than they are. Nevertheless, they know very well that they can always rely on him, and that he will always offer a helping hand when asked.

Dear Jan, all your friends and colleagues from the scientific community wish you many more happy and active years among us!

\author{
Aleš Kroupa \\ Guest Editor, Journal of Phase Equilibria and Diffusion \\ Institute of Physics of Materials \\ Czech Academy of Sciences \\ Brno, Czech Republic
}

\author{
Andy Watson \\ Associate Editor, Journal of Phase Equilibria and \\ Diffusion \\ Coventry University \\ England
}

